\title{
STABILITY INDICATING HPLC METHOD FOR SIMULTANEOUS DETERMINATION OF MOXIFLOXACIN HYDROCHLORIDE AND KETOROLAC TROMETHAMINE IN PHARMACEUTICAL FORMULATIONS
}

\author{
Syed Naeem Razzaq and Islam Ullah Khan \\ Department of Chemistry, Government College University, Lahore-54000, Pakistan \\ Muhammad Ashfaq* \\ Department of Chemistry, University of Gujrat, H.H. Campus, Gujrat-50700, Pakistan \\ Irfana Mariam \\ Department of Chemistry, Queen Marry College, Lahore-54000 Pakistan
}

Recebido em 8/8/11; aceito em 30/12/11; publicado na web em 15/5/12

\begin{abstract}
A simple, RP-HPLC method was established for determining moxifloxacin and ketorolac in pharmaceutical formulations. Moxifloxacin, ketorolac and their degradation products were separated using $\mathrm{C}_{8}$ column with methanol and phosphate buffer $\mathrm{pH}$ $3.0(55: 45 \mathrm{v} / \mathrm{v})$ as the mobile phase. Detection was performed at $243 \mathrm{~nm}$ using a diode array detector. The method was validated using ICH guidelines and was linear in the range $20-140 \mu \mathrm{g} \mathrm{mL}^{-1}$ for both analytes. Good separation of both the analytes and their degradation products was achieved using this method. The developed method can be applied successfully for the determination of moxifloxacin and ketorolac.
\end{abstract}

Keywords: reverse phase liquid chromatography; moxifloxacin hydrochloride; ketorolac tromethamine.

\section{INTRODUCTION}

Safety and efficacy are two fundamental properties of drug products. Instability of drug products can cause changes in the physical, chemical, pharmacological and toxicological properties of their active pharmaceutical ingredients (API). Therefore pharmacists should take various factors into consideration, for example drug stability, possible degradation products and potential interactions with the excipients used in the formulation, to ensure successful therapy. A stability-indicating procedure is one which, based on the characteristic structural, chemical, or biological properties of each active ingredient of a drug product, will distinguish each active ingredient from its degradation products so that the active ingredient content can be accurately measured. ${ }^{1}$ It is recommended by both the ICH and the WHO that analysis of drugs during stability testing should be conducted by use of a validated stability-indicating method. In this paper, ICH and WHO guidelines were therefore heeded for the simultaneous determination of moxifloxacin and ketorolac.

Moxifloxacin hydrochloride is chemically designated as 1-Cyclopropyl-6-fluoro-1,4- dihydro-8-methoxy-7-[(4aS,7aS)-octahydro-6H-pyrrolo[3,4-b]pyridin-6-yl]-4-oxo-3 quinolinecarboxylic acid hydrochloride. It is a broad-spectrum antibiotic that functions by inhibiting DNA gyrase, a type II topoisomerase, and topoisomerase IV, ${ }^{2}$ enzymes necessary to separate bacterial DNA, thereby inhibiting cell replication. The antibiotic is used for bacterial conjunctivitis, keratitis, pre and post operatively to control eye infections. Ketorolac tromethamine chemically designated as ( \pm )-5-benzoyl-2,3-dihydro-1H-pyrrolizine-1-carboxylic acid, a compound with 2-amino-2-(hydroxymethyl)-1,3-propanediol, a pyrrolizine carboxylic acid derivative structurally related to indomethacin, is an NSAID, used principally as an analgesic. ${ }^{3}$ Both moxifloxacin hydrochloride and ketorolac tromethamine have been analysed by various techniques both alone and in combination with other drugs. The analytical methods available for moxifloxacin hydrochloride included determination by spectrophotometry, ${ }^{4-6}$ and

*e-mail: m.ashfaq@uog.edu.pk high performance liquid chromatography. ${ }^{7-15}$ The analytical methods available for ketorolac tromethamine included determination by flow injection analysis, ${ }^{16}$ gas chromatography-mass spectrometry ${ }^{17}$ and HPLC. ${ }^{18-26}$<smiles>COc1c(N2CC3CCCNC3C2)c(F)cc2c(=O)c(C(=O)O)cn(C3CC3)c12</smiles>

Moxifloxacin Hydrochloride<smiles>NC(CO)(CO)CO</smiles>

Ketorolac Tromethamine

The combination of moxifloxacin and ketorolac has not been adopted by any official pharmacopoeia. An extensive review of the literature revealed no HPLC method for simultaneous determination of both drugs. Therefore attempts were made to develop and validate simple, precise, sensitive and isocratic reverse phase high performance liquid chromatographic method for simultaneous determination of both drugs along with their stress-induced degradation products in pharmaceutical formulations.

\section{EXPERIMENTAL}

\section{Chemicals and reagents}

Reference standards of moxifloxacin hydrochloride and ketorolac tromethamine with stated purity of 99.97 and $99.88 \%$, respectively 
were obtained from Schazoo Zaka Laboratories (Lahore, Pakistan). Moxiflox Plus and Moxicip KT eye drops, claiming to contain $5 \mathrm{mg}$ each of the drug per $\mathrm{mL}$, were used in this study. Methanol (HPLC grade), potassium dihydrogen phosphate, phosphoric acid, triethylamine, sodium hydroxide, hydrochloric acid and hydrogen peroxide (analytical reagent grade) were from M.S Traders Lahore, Pakistan (Fluka origin). Double distilled water was used throughout the analysis. Mobile phase was filtered using $0.45 \mu \mathrm{m}$ nylon filters by Millipore (USA).

\section{Equipment and chromatographic conditions}

The HPLC system consisted of a Shimadzu LC-20A system (Kyoto, Japan) equipped with a model LC-20AT pump, SPD-M20A Diode array detector (set at $243 \mathrm{~nm}$ ), and a DGU-20A5 online degasser, and a Rheodyne injection valve with a $20 \mu \mathrm{L}$ loop. Peak areas were integrated using a Shimadzu LC solution (version 1.227) software program. The experimental conditions were optimized on a BDS Hypersil $\mathrm{C}_{8}$ column $(250 \times 4.6 \mathrm{~mm}, 5 \mu \mathrm{m}$ particle size $)$ at room temperature. Mobile phase consisted of methanol and phosphate buffer ( $\mathrm{pH} 3.0)$ in the ratio of (55:45 v/v, respectively). The phosphate buffer was prepared by taking $2.72 \mathrm{~g}$ of potassium dihydrogen phosphate in $1000 \mathrm{~mL}$ of water. Triethylamine $(1 \mathrm{~mL})$ was added to it and $\mathrm{pH}$ then adjusted to 3.0 using phosphoric acid. Flow rate of the mobile phase was $0.7 \mathrm{~mL} \mathrm{~min}{ }^{-1}$ and all chromatographic experiments were performed at room temperature $\left(25^{\circ} \mathrm{C} \pm 2{ }^{\circ} \mathrm{C}\right)$.

\section{Preparation of standard solution}

Standard stock solution was prepared by accurately weighing $100 \mathrm{mg}$ of moxifloxacin and $100 \mathrm{mg}$ of ketorolac tromethamine and then both dissolved in $100 \mathrm{~mL}$ of mobile phase. $2 \mathrm{~mL}$ of the standard stock solution was diluted to $25 \mathrm{~mL}$ with mobile phase to prepare working standard solution having a concentration of $80 \mu \mathrm{g} \mathrm{mL}^{-1}$ for both moxifloxacin and ketorolac tromethamine. The solution was filtered through a $0.45 \mu \mathrm{m}$ nylon filter before analysis.

\section{Preparation of sample solution}

$4 \mathrm{~mL}$ commercial eye drops were diluted to $50 \mathrm{~mL}$ with mobile phase. $5 \mathrm{~mL}$ of this solution was then diluted to $25 \mathrm{~mL}$ with mobile phase to obtain a concentration of $80 \mu \mathrm{g} \mathrm{mL}^{-1}$ for both moxifloxacin and ketorolac tromethamine. The solution was filtered through a 0.45 $\mu \mathrm{m}$ nylon filter before analysis.

\section{Linearity}

Linear calibration plots of the proposed method were obtained over concentration ranges of $20-140 \mu \mathrm{g} \mathrm{mL}^{-1}$ for both moxifloxacin and ketorolac tromethamine $(20,40,60,80,100,120$, and $140 \mu \mathrm{g}$ $\left.\mathrm{mL}^{-1}\right)$. Each solution was prepared in triplicate.

\section{Accuracy}

The standard addition method was used to demonstrate the accuracy of the proposed method. For this purpose, known quantities of moxifloxacin and ketorolac tromethamine were supplemented to the previously analysed sample solution and then experimental and true values compared. Three levels of solutions were made corresponding to 70,100 and $130 \%$ of nominal analytical concentration $\left(80 \mu \mathrm{g} \mathrm{mL}^{-1}\right)$.

\section{Precision}

Repeatability was studied by determination of intra-day and inter-day precision. Intra-day precision was determined by injecting five standard solutions of three different concentrations on the same day whereas inter-day precision was determined by injecting the same solutions for three consecutive days. Relative standard deviation $(\mathrm{RSD} \%)$ of the peak area was then calculated to represent precision.

\section{Specificity (stress testing)}

Stress testing was carried out using different $\mathrm{ICH}$ prescribed stress conditions such as acidic, basic, oxidative, photolytic and thermal stresses. All stress studies were performed in a $25 \mathrm{~mL}$ volumetric flask.

\section{Acid degradation studies}

Acid degradation studies were performed under 3 different temperature conditions using $1 \mathrm{M} \mathrm{HCl}$ and $5 \mathrm{M} \mathrm{HCl}$. For this purpose, $2 \mathrm{~mL}$ of the standard stock solution was taken and placed into five different $25 \mathrm{~mL}$ volumetric flasks. $2 \mathrm{~mL}$ of $1 \mathrm{M} \mathrm{HCl}$ was added to two of these flasks, one of which was kept at room temperature for $19 \mathrm{~h}$ and the other at $40{ }^{\circ} \mathrm{C}$ for $1 \mathrm{~h}$. For the remaining three $25 \mathrm{~mL}$ volumetric flasks, $2 \mathrm{~mL}$ of $5 \mathrm{M} \mathrm{HCl}$ was added to each. Out of these three flasks, one was kept at room temperature for $19 \mathrm{~h}$, a second at $40{ }^{\circ} \mathrm{C}$ for $1 \mathrm{~h}$, and the third was heated at $160{ }^{\circ} \mathrm{C}$ on a hot plate for $1 \mathrm{~h}$. After completion of the stress procedure, all the solutions were neutralized by using $1 \mathrm{M}$ and $5 \mathrm{M} \mathrm{NaOH}$ and completed up to the mark with mobile phase.

\section{Base degradation studies}

Base degradation studies were performed under 3 different temperature conditions using $1 \mathrm{M} \mathrm{NaOH}$ and $5 \mathrm{M} \mathrm{NaOH}$. For this purpose, $2 \mathrm{~mL}$ of the standard stock solution was taken and placed into 5 different $25 \mathrm{~mL}$ volumetric flasks. $2 \mathrm{~mL}$ of $1 \mathrm{M} \mathrm{NaOH}$ was added to 2 of these flasks, one of which was kept at room temperature for $19 \mathrm{~h}$ and the other at $40{ }^{\circ} \mathrm{C}$ for $1 \mathrm{~h}$. For the remaining three 25 $\mathrm{mL}$ volumetric flasks, $2 \mathrm{~mL}$ of $5 \mathrm{M} \mathrm{NaOH}$ was added to each. Out of these 3 flasks, one was kept at room temperature for $19 \mathrm{~h}$, the second at $40{ }^{\circ} \mathrm{C}$ for $1 \mathrm{~h}$ and the third was heated at $160^{\circ} \mathrm{C}$ on a hot plate for $1 \mathrm{~h}$. After completion of the stress procedure, all the solutions were neutralized by using $1 \mathrm{M}$ and $5 \mathrm{M} \mathrm{HCl}$ and completed up to the mark with mobile phase.

\section{Oxidative degradation studies}

Oxidative degradation studies were performed under 3 different temperature conditions using $6 \% \mathrm{H}_{2} \mathrm{O}_{2}$. For this purpose, $2 \mathrm{~mL}$ of the standard stock solution was taken and placed into 3 different $25 \mathrm{~mL}$ volumetric flasks. $2 \mathrm{~mL}$ of $6 \% \mathrm{H}_{2} \mathrm{O}_{2}$ was added to each of these flasks, one of which was kept at room temperature for $19 \mathrm{~h}$, the second at 40 ${ }^{\circ} \mathrm{C}$ for $1 \mathrm{~h}$ and the third heated at $160{ }^{\circ} \mathrm{C}$ on a hot plate for $1 \mathrm{~h}$. After completion of the stress procedure, all the solutions were completed up to the mark with mobile phase.

\section{Photolytic degradation studies}

For photolytic degradation, $2 \mathrm{~mL}$ of standard stock solution was placed in direct sunlight for $1 \mathrm{~h}$.

\section{Thermal degradation studies}

Thermal degradation studies were performed under 3 different temperature conditions. For this purpose, $2 \mathrm{~mL}$ of the standard stock 
solution was taken and placed in 3 different $25 \mathrm{~mL}$ volumetric flasks. One of the volumetric flasks was kept at room temperature for 19 $\mathrm{h}$ and a second at $40{ }^{\circ} \mathrm{C}$ for $1 \mathrm{~h}$. The third $25 \mathrm{~mL}$ volumetric flask was heated at $160{ }^{\circ} \mathrm{C}$ on a hot plate for $1 \mathrm{~h}$. After completion of the stress procedure, all the solutions were completed up to the mark with mobile phase.

\section{Robustness}

Premeditated variations were performed under the experimental conditions of the proposed method to assess the method's robustness. For this purpose, minor changes were made in mobile phase composition, flow rate and $\mathrm{pH}$ of the buffer solution. The effect of these changes on chromatographic parameters such as retention time, tailing factor and number of theoretical plates was then measured.

\section{Limit of detection and limit of quantitation}

To calculate limits of detection (LOD) and limits of quantitation (LOQ), sequential dilutions were done and analysed by the proposed method. The LOD and LOQ were then established by evaluating the level (signal to noise ratio of 3:1 and 10:1, respectively) at which the analytes were readily detected and accurately quantified.

\section{RESULTS AND DISCUSSION}

In this work, a simple, sensitive and accurate isocratic RP-HPLC method for simultaneous determination of moxifloxacin, ketorolac and their stress-induced degradation products was proposed. Both drugs contain basic nitrogen atoms and therefore have the potential to cause peak tailing due to interactions of these basic nitrogen atoms with the silanol groups of the stationary phase during chromatographic separation. In order to obtain symmetrical peaks with better resolution, the chromatographic conditions i.e. $\mathrm{pH}$ of the buffer, concentration of organic modifier and silanol blockers were optimized. Various chromatographic conditions such as mobile phase composition, analytical columns with different packing materials $\left(\mathrm{C}_{8}, \mathrm{C}_{18}\right.$, phenyl, cyano), and configurations (10, 15, $25 \mathrm{~cm}$ columns) were used to obtain sharp peaks with reduced tailing, and better resolution with no peak impurity. Finally, a base deactivated silica end-capped BDS Hypersil $\mathrm{C}_{8}$ column was selected which provided reduced peak tailing and acceptable peak purity index. Mobile phase composition was selected based upon peak parameters (symmetry, tailing, resolution and peak purity index etc.), run time, ease of preparation and cost. The most suitable mobile phase composition was found to be methanol and phosphate buffer $(\mathrm{pH} 3.0)$ in the ratio of 55:45 (v/v), respectively. Under the chromatographic conditions outlined, highly symmetrical and sharp peaks of moxifloxacin and ketorolac were obtained at retention times of 5.25 and 11.49 min, respectively (Figure 1).

The chromatographic method developed was validated using ICH guidelines. ${ }^{27}$ Validation parameters include linearity, accuracy, precision, robustness, specificity, limit of detection and quantitation.

Linear calibration plots for the proposed method were obtained in a concentration range of 20 to $140 \mu \mathrm{g} \mathrm{mL}^{-1}$ for both moxifloxacin and ketorolac $\left(20,40,60,80,100,120\right.$ and $\left.140 \mu \mathrm{g} \mathrm{mL}^{-1}\right)$. The linear regression equation for moxifloxacin was found to be $\mathrm{Y}=13892 \mathrm{X}$

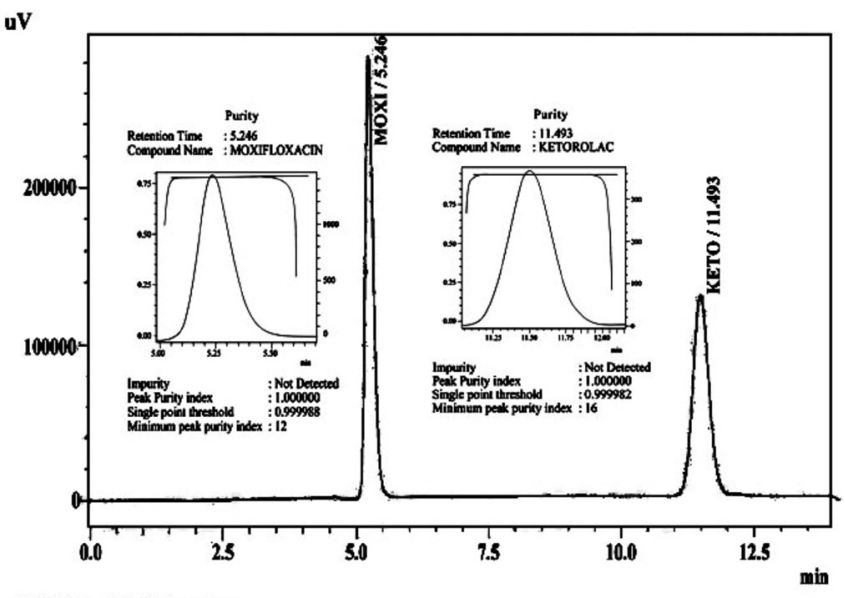

1 PDA Multi 1/243um 4um

Figure 1. Chromatogram of Moxifloxacin and Ketorolac in pharmaceutical formulation

+54497 whereas for ketorolac, was $\mathrm{Y}=84857 \mathrm{X}+334286$. The correlation coefficient for both the drugs was equal to 0.9999 . The results of the regression statistics of moxifloxacin and ketorolac are given in Table 1. The residual plots of moxifloxacin and ketorolac are shown in Figures $2 \mathrm{a}$ and $2 \mathrm{~b}$. The residual plots of the moxifloxacin and ketorolac clearly indicated that the data points (positive and negative values as bar graph) are evenly distributed around a horizontal line. It was thus concluded that the straight line function was appropriate for both the drugs.

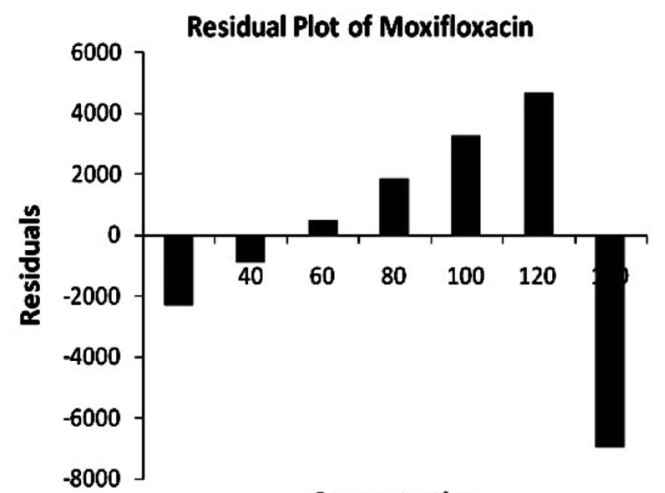

Concentration

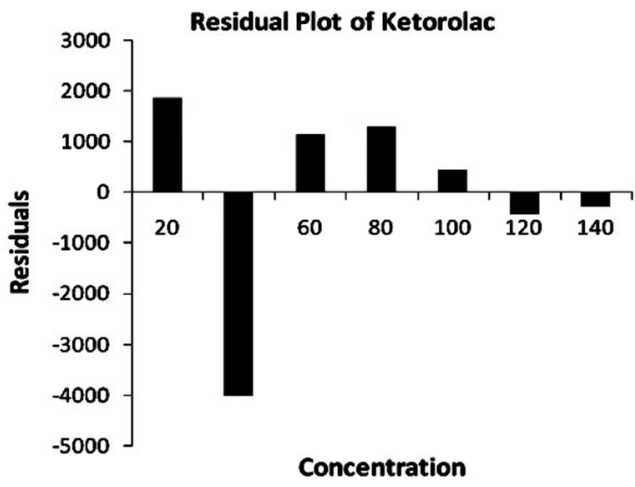

Figure 2. Residual plot of a) Moxifloxacin; b) Ketorolac

Table 1. Regression statistics of the proposed method

\begin{tabular}{lccccc}
\hline Drugs & Regression equation & Conc. Range $\left(\mu \mathrm{g} \mathrm{mL} \mathrm{mL}^{-1}\right)$ & $\mathrm{LOD}(\mu \mathrm{g} \mathrm{mL}-1)$ & $\mathrm{LOQ}\left(\mu \mathrm{g} \mathrm{mL} \mathrm{m}^{-1}\right)$ & 0.53 \\
\hline Moxifloxacin & $\mathrm{Y}=13892 \mathrm{X}+54497$ & $20-140$ & 0.16 & 0.9999 \\
Ketorolac & $\mathrm{Y}=84857 \mathrm{X}+334286$ & $20-140$ & 0.18 & 0.60 & 0.9999 \\
\hline
\end{tabular}


The limits of detection (LOD) and quantitation (LOQ) were determined by making serials of dilutions. LOD was found to be $0.16 \mu \mathrm{g} \mathrm{mL}^{-1}$ and $0.18 \mu \mathrm{g} \mathrm{mL}^{-1}$ for moxifloxacin and ketorolac tromethamine, respectively (signal to noise ratio of $3: 1$ ). LOQ was found to be 0.53 and $0.60 \mu \mathrm{g} \mathrm{mL}^{-1}$ for moxifloxacin and ketorolac tromethamine, respectively (signal to noise ratio of 10:1). LOD and LOQ values show that the method can be used for analysis of these drugs at very low concentrations, which in some cases during stability studies is very challenging.

Accuracy of the method was determined by the standard addition technique. Three levels of solutions $(70,100$ and $130 \%)$ of the nominal analytical concentrations were prepared. Percentage recoveries, along with standard deviation and relative standard deviations for each analyte $(n=5)$ are given in Table 2 . From the data given in Table 2, it is clear that the method is highly accurate and suitable for the intended use.

Table 2. Accuracy of the proposed HPLC method

\begin{tabular}{lccc}
\hline Drugs & $\begin{array}{c}\text { Spiked } \\
\text { concentration } \\
\left(\mu \mathrm{g} \mathrm{mL}^{-1}\right)\end{array}$ & $\begin{array}{c}\text { Measured } \\
\text { concentration } \\
\left(\mu \mathrm{gL}^{-1}\right) \pm \mathrm{SD} ; \\
\mathrm{RSD}(\%)\end{array}$ & Recovery $(\%)$ \\
\hline Moxifloxacin & 56 & $55.5 \pm 0.3 ; 0.6$ & 99 \\
& 80 & $80.8 \pm 0.5 ; 0.6$ & 101 \\
\hline Ketorolac & 104 & $105.1 \pm 0.9 ; 0.9$ & 101 \\
& 56 & $55.9 \pm 0.5 ; 1.0$ & 100 \\
& 80 & $79.1 \pm 0.3 ; 0.4$ & 99 \\
\hline
\end{tabular}

$\mathrm{n}=$ Average of 5 analysis

Intra-day precision was determined by injecting 5 standard solutions of 3 different concentrations on the same day $(n=5)$ whereas inter-day precision was determined by injecting the same solutions for 3 consecutive days. Relative standard deviation (RSD \%) of the peak area was calculated to represent precision. The results of intra-day and inter-day precision are shown in Table 3. RSD values were less than $2 \%$ for intra and inter day precisions, indicating high precision of the method.

Table 3. Intra-day and inter-day precision of the proposed HPLC method

\begin{tabular}{lccc}
\hline Drugs & $\begin{array}{c}\text { Actual } \\
\text { concentration } \\
\left.(\mu \mathrm{g} \mathrm{mL})^{-1}\right)\end{array}$ & $\begin{array}{c}\text { Intra-day precision } \\
\text { Measured } \\
\text { concentration } \pm \text { SD; } \\
\text { RSD }(\%)\end{array}$ & $\begin{array}{c}\text { Inter-day precision } \\
\text { Measured } \\
\text { concentration } \pm S D ; \\
\text { RSD }(\%)\end{array}$ \\
\hline Moxifloxacin & 56 & $56.1 \pm 0.7 ; 1.2$ & $56.8 \pm 0.9 ; 1.6$ \\
& 80 & $80.5 \pm 1.0 ; 1.3$ & $80.4 \pm 1.2 ; 1.5$ \\
\hline Ketorolac & 104 & $104.9 \pm 1.6 ; 1.5$ & $104.2 \pm 1.8 ; 1.7$ \\
\hline & 56 & $57.2 \pm 0.7 ; 1.2$ & $56.8 \pm 0.8 ; 1.4$ \\
& 80 & $79.9 \pm 0.9 ; 1.1$ & $80.2 \pm 1.0 ; 1.3$ \\
\hline
\end{tabular}

$\mathrm{n}=$ Average of 5 analyses

Robustness of the method was ascertained by slightly varying the chromatographic conditions. The results showed that slight variations in chromatographic conditions had negligible effect on the chromatographic parameters. The results of the robustness study are given in Table 4.

Specificity of the developed method was evaluated by applying different stress conditions (acid, base, oxidation, photolytic and
Table 4. Robustness study of Moxifloxacin and Ketorolac

\begin{tabular}{|c|c|c|c|c|}
\hline \multicolumn{5}{|l|}{ Moxifloxacin } \\
\hline $\begin{array}{l}\text { Chromatographic } \\
\text { Conditions }\end{array}$ & Assay \% & $\mathrm{t}_{\mathrm{R}}(\min )$ & $\begin{array}{l}\text { Theoretical } \\
\text { plate }\end{array}$ & Tailing \\
\hline $\begin{array}{l}\text { Methanol:buffer } \\
(53: 47)\end{array}$ & 100.82 & 5.472 & 5518 & 1.17 \\
\hline $\begin{array}{l}\text { Methanol:buffer } \\
(55: 45)\end{array}$ & 99.56 & 5.273 & 5591 & 1.13 \\
\hline $\begin{array}{l}\text { Methanol:buffer } \\
(57: 43)\end{array}$ & 100.25 & 5.121 & 5522 & 1.18 \\
\hline $\begin{array}{l}\text { Flow rate }(0.6 \mathrm{~mL} \\
\left.\min ^{-1}\right)\end{array}$ & 100.75 & 6.092 & 5512 & 1.22 \\
\hline $\begin{array}{l}\text { Flow rate }(0.8 \mathrm{~mL} \\
\left.\mathrm{min}^{-1}\right)\end{array}$ & 99.39 & 4.710 & 5588 & 1.32 \\
\hline Buffer (pH 2.8) & 99.59 & 5.176 & 5511 & 1.17 \\
\hline Buffer (pH 3.2) & 99.36 & 5.340 & 5537 & 1.18 \\
\hline \multicolumn{5}{|l|}{ Ketorolac } \\
\hline $\begin{array}{l}\text { Chromatographic } \\
\text { Conditions }\end{array}$ & Assay \% & $\mathrm{t}_{\mathrm{R}}(\min )$ & $\begin{array}{l}\text { Theoretical } \\
\text { plate }\end{array}$ & Tailing \\
\hline $\begin{array}{l}\text { Methanol:buffer } \\
(53: 47)\end{array}$ & 100.08 & 11.931 & 6850 & 1.11 \\
\hline $\begin{array}{l}\text { Methanol:buffer } \\
(55: 45)\end{array}$ & 100.71 & 11.491 & 6865 & 1.12 \\
\hline $\begin{array}{l}\text { Methanol:buffer } \\
(57: 43)\end{array}$ & 100.22 & 11.143 & 6890 & 1.20 \\
\hline $\begin{array}{l}\text { Flow rate }(0.6 \mathrm{~mL} \\
\left.\min ^{-1}\right)\end{array}$ & 99.91 & 13.321 & 6821 & 1.11 \\
\hline $\begin{array}{l}\text { Flow rate }(0.8 \mathrm{~mL} \\
\left.\mathrm{min}^{-1}\right)\end{array}$ & 100.49 & 10.068 & 6870 & 1.19 \\
\hline Buffer (pH 2.8) & 99.66 & 11.322 & 6861 & 1.17 \\
\hline Buffer (pH 3.2) & 99.09 & 11.567 & 6869 & 1.11 \\
\hline
\end{tabular}

thermal) to moxifloxacin and ketorolac tromethamine in combination form. The chromatograms under different stress conditions are shown in Figures 3, 4, 5 and 6. The results of stress studies are given in Table 5. Based on the results, it is evident that under mild conditions neither of the drugs were degraded, remaining intact except under photolytic conditions where moxifloxacin was degraded up to $16 \%$ whereas ketorolac was degraded up to $36 \%$. All the stress conditions (except thermal) applied at $160{ }^{\circ} \mathrm{C}$ were able to degrade both the drugs within $1 \mathrm{~h}$. Comparison of the two drugs showed that moxifloxacin was more stable compared to ketorolac. Greatest degradation of ketorolac occurred under acidic conditions at $160{ }^{\circ} \mathrm{C}$ whereas greatest degradation of moxifloxacin was produced under photolytic conditions.

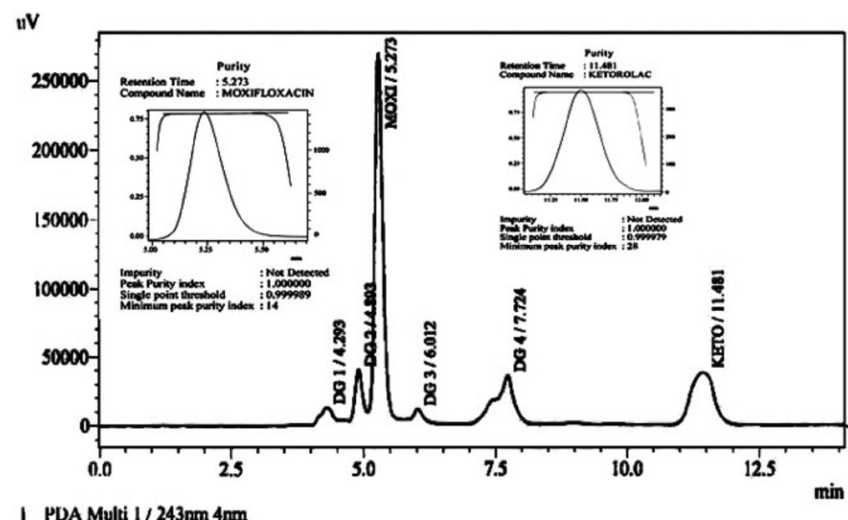

Figure 3. Chromatogram of Moxifloxacin and Ketorolac under acidic stress at $160^{\circ} \mathrm{C}$ on hot plate 


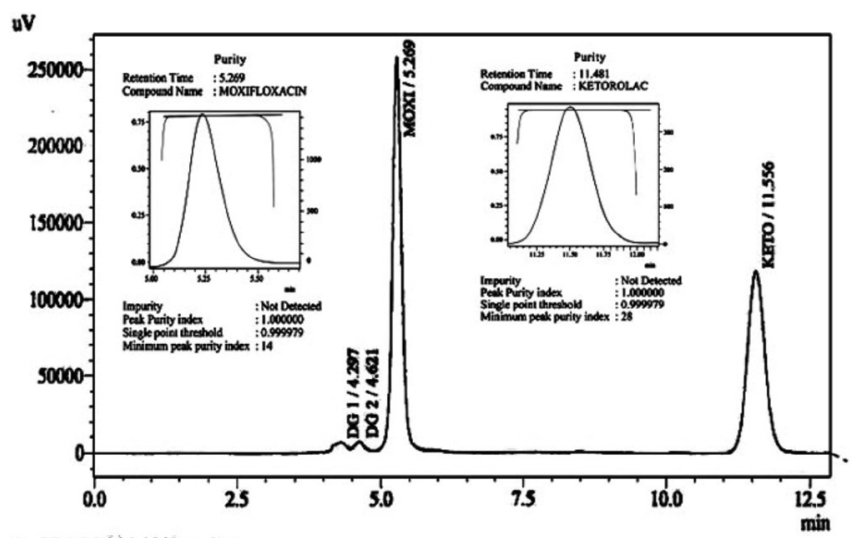

1 PDA Multi I / 243nm 4mm

Figure 4. Chromatogram of Moxifloxacin and Ketorolac under basic stress at $160{ }^{\circ} \mathrm{C}$ on hot plate

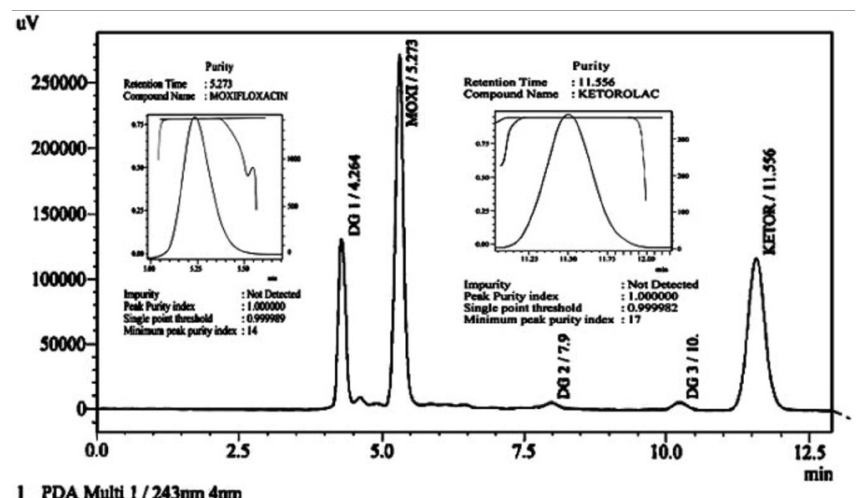

Figure 5. Chromatogram of Moxifloxacin and Ketorolac under oxidative stress at $160^{\circ} \mathrm{C}$ on hot plate

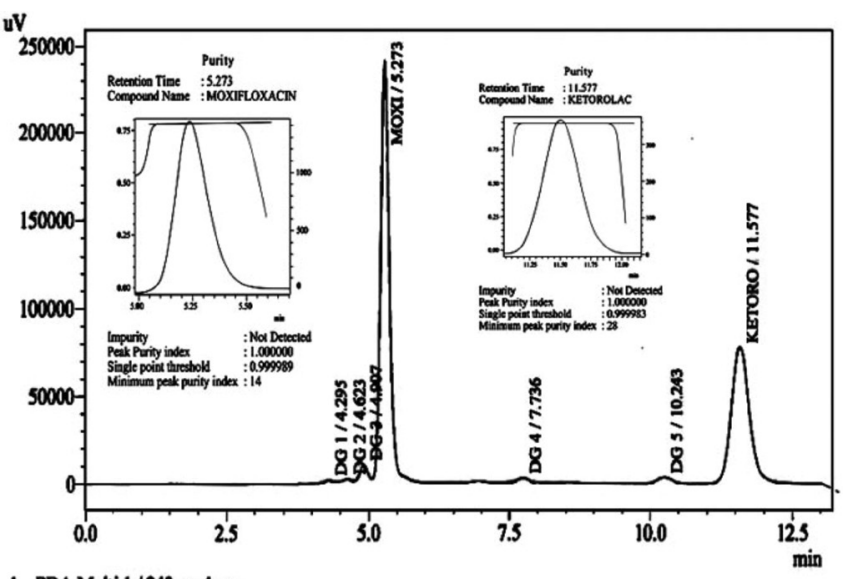

I PDA Multi I / 243nm 4nm

Figure 6. Chromatogram of Moxifloxacin and Ketorolac under photolytic stress

In addition to the percentage degradation of each drug, a number of degradation products (impurities) were produced under all the stress conditions except thermal. The first degradation product (impurity) under acidic stress was produced at $4.2 \mathrm{~min}$ and this degradation product was also produced under all other stress conditions, which showed the same degradation pattern up to degradation product one. The second degradation product produced at 4.6 min under basic stress was also common with the degradation under photolytic conditions. The degradation product at 4.9 and $7.7 \mathrm{~min}$ were common in acidic and photolytic conditions but absent under other stress conditions. Similarly, a degradation product at 10.2 min was common under both oxidative and photolytic conditions. There were several other degradation products (impurities) which were unique to acidic (6.01 $\mathrm{min}$ ) and oxidative (7.96 min) stress conditions.

Chromatographic data of the stress-induced degradation products are provided in Table 6 . Application of the proposed method was

Table 5. Stress testing results of Moxifloxacin and Ketorolac

\begin{tabular}{|c|c|c|c|c|c|}
\hline Nature of stress & Temperature $\left({ }^{\circ} \mathrm{C}\right)$ & Time (h) & $\begin{array}{c}\text { Amount of Moxifloxacin } \\
\text { Remaining } \pm \text { RSD }(\%)\end{array}$ & $\begin{array}{l}\text { Amount of Ketorolac } \\
\text { Remaining } \pm \text { RSD }(\%)\end{array}$ & Extent of Decomposition \\
\hline \multirow[t]{2}{*}{$1 \mathrm{M} \mathrm{HCl}$} & 25 & 19 & $99.3 \pm 1.3$ & $100.0 \pm 0.6$ & None \\
\hline & 40 & 1 & $100.0 \pm 0.3$ & $98.2 \pm 1.2$ & None \\
\hline \multirow[t]{3}{*}{$5 \mathrm{M} \mathrm{HCl}$} & 25 & 19 & $101.2 \pm 0.9$ & $100.6 \pm 0.2$ & None \\
\hline & 40 & 1 & $100.6 \pm 0.3$ & $99.9 \pm 1.0$ & None \\
\hline & $160(\mathrm{HP})$ & 1 & $89.4 \pm 0.4(\mathrm{PPI}=1.0000)$ & $41.6 \pm 0.9(P P I=1.0000)$ & Substantial \\
\hline \multirow[t]{2}{*}{$1 \mathrm{M} \mathrm{NaOH}$} & 25 & 19 & $99.1 \pm 0.7$ & $100.2 \pm 0.6$ & None \\
\hline & 40 & 1 & $100.2 \pm 0.3$ & $99.4 \pm 0.9$ & None \\
\hline \multirow[t]{3}{*}{$5 \mathrm{M} \mathrm{NaOH}$} & 25 & 19 & $101.7 \pm 1.1$ & $101.3 \pm 0.4$ & None \\
\hline & 40 & 1 & $99.0 \pm 0.4$ & $100.1 \pm 0.9$ & None \\
\hline & $160(\mathrm{HP})$ & 1 & $94.6 \pm 0.2(P P I=1.0000)$ & $93.7 \pm 0.7(P P I=1.0000)$ & Slight \\
\hline \multirow[t]{3}{*}{$6 \% \mathrm{H}_{2} \mathrm{O}_{2}$} & 25 & 19 & $101.2 \pm 0.9$ & $100.5 \pm 0.5$ & None \\
\hline & 40 & 1 & $99.9 \pm 0.2$ & $98.8 \pm 1.8$ & None \\
\hline & $160(\mathrm{HP})$ & 1 & $91.6 \pm 0.2(P P I=1.0000)$ & $92.0 \pm 0.9(P P I=1.0000)$ & Slight \\
\hline Photolytic & Sunlight & 1 & $84.2 \pm 1.6(P P I=1.0000)$ & $63.8 \pm 1.9(P P I=1.0000)$ & Substantial \\
\hline \multirow[t]{3}{*}{ Thermal } & 25 & 19 & $100.6 \pm 0.4$ & $101.3 \pm 1.6$ & None \\
\hline & 40 & 1 & $98.9 \pm 1.1$ & $102.0 \pm 0.3$ & None \\
\hline & $160(\mathrm{HP})$ & 1 & $100.0 \pm 1.0(P P I=1.0000)$ & $100.8 \pm 0.9(P P I=1.0000)$ & None \\
\hline
\end{tabular}

$\mathrm{n}=$ Average of 3 determinations, $\mathrm{HP}=$ Hot plate, PPI = Peak Purity Index 
Table 6. Chromatographic data of stress induced degradation products

\begin{tabular}{ccc}
\hline Nature of Stress & Retention times (minutes) & Number of theoretical plates \\
\hline Acidic & $4.293 ; 4.893 ; 6.012 ; 7.724$ & $1981 ; 6188 ; 6716 ; 3892$ \\
Basic & $4.297 ; 4.621$ & $2504 ; 5136$ \\
Oxidative & $4.264 ; 7.969 ; 10.229$ & $5250 ; 6142 ; 7517$ \\
Photolytic & $4.295 ; 4.623 ; 4.907 ; 7.736 ; 10.243$ & $5175 ; 8553 ; 6982 ; 6499 ; 7168$ \\
Thermal & $--.879 ; 1.155$ & $0.903 ; 0.845 ; 1.060 ; 0.923 ; 1.088$ \\
\hline
\end{tabular}

$\mathrm{n}=$ Average of 3 determinations

Table 7. Assay results of Moxifloxacin and Ketorolac Tromethamine in commercial eye drops

\begin{tabular}{|c|c|c|c|c|}
\hline Products & Ingredient & Label value $\left(\mathrm{mg} \mathrm{mL}^{-1}\right)$ & Found (mg) & Recovery \pm RSD (\%) \\
\hline \multirow[t]{2}{*}{ Moxiflox plus } & Moxifloxacin & 5 & 5.02 & $100.4 \pm 0.2$ \\
\hline & Ketorolac Tromethamine & 5 & 4.99 & $99.8 \pm 0.8$ \\
\hline \multirow[t]{2}{*}{ Moxicip KT } & Moxifloxacin & 5 & 5.02 & $100.4 \pm 0.2$ \\
\hline & Ketorolac Tromethamine & 5 & 5.00 & $100.0 \pm 0.1$ \\
\hline
\end{tabular}

$\mathrm{n}=$ Average of 10 determinations

checked by analyzing the moxifloxacin and ketorolac in commercially available pharmaceutical products. The results are provided in Table 7, showing high percentage recoveries and low RSD (\%) values for both analytes.

\section{CONCLUSION}

A simple, sensitive, and accurate method using reverse phase HPLC was described for simultaneous determination of moxifloxacin hydrochloride and ketorolac tromethamine in pharmaceutical formulations. The proposed method was validated by testing its linearity, accuracy, precision, limits of detection, and quantitation, and specificity. The method proved able to separate the peaks of active pharmaceutical ingredients (APIs) from the degradation products (produced during forced degradation studies). It is also clear from the chromatograms that both the active ingredient peaks under all the stress conditions were free from any sort of degradation impurities. Taken together, these results allow us to conclude that the method can be successfully used for all stability and validation studies.

\section{REFERENCES}

1. FDA; Guidelines for submitting documentation for the stability of human drugs and biologics, 1987.

2. Drlica, K.; Zhao, X.; Microbiol. Mol. Bio. Rev. 1997, 61, 377.

3. Reynolds, J. E. F.; Martindale, The Extra Pharmacopoeia, $36^{\text {th }}$ ed., Pharmaceutical Press: London, 2009, p. 74.

4. Misra, M.; Misra, A. K.; Zope, P.; Panpalia, G. M.; Dorle, A. K.; J. Global Pharma. Technol. 2010, 2, 21.

5. Vandana; Chaudhary, A. K.; African Journal of Pharmaceutical Sciences and Pharmacy 2010, 1, 50.

6. Motwani, S. K.; Chopra, S.; Ahmad, F. J.; Khar, R. K.; Spectrochim. Acta 2007, 68, 250.

7. Sultana, N.; Akhtar, M.; Shamim, S.; Gul, S.; Arayne, M. S.; Quim. Nova 2011, 34, 683.

8. Sultana, N.; Arayne, M. S.; Akhtar, M.; Shamim, S.; Gul, S.; Khan, M. M.; J. Chin. Chem. Soc. 2010, 57, 1.
9. Xu, Y. H.; Li, D.; Liu, X. Y.; Li, Y. Z.; Lu, J.; J. Chromatogr., B: Anal. Technol. Biomed. Life Sci. 2010, 878, 3437.

10. Devi, M. L.; Chandrasekhar, K. B.; Chromatographia 2009, 69, 993.

11. Djurdjevic, P.; Ciric, A.; Djurdjevic, A.; Stankov, M. J.; J. Pharm. Biomed. Anal. 2009, 50, 117.

12. Hemanth, K. A. K.; Ramachandran, G.; J. Chromatogr., B: Anal. Technol. Biomed. Life Sci. 2009, 877, 1205.

13. Laban-Djurdjevic, A.; Jelikic-Stankov, M.; Djurdjevic, P.; J. Chromatogr., B: Anal. Technol. Biomed. Life Sci. 2006, 844, 104.

14. Nguyen, H. A.; Grellet, J.; Ba, B. B.; Quentin, C.; Saux, M. C.; J. Chromatogr., B: Anal. Technol. Biomed. Life Sci. 2004, 810, 77.

15. Ba, B. B.; Etienne, R.; Ducint, D.; Quentin, C.; Saux, M. C.; J. Chromatogr., B: Anal. Technol. Biomed. Life Sci. 2001, 754, 107.

16. Kamath, B. V.; Shivram, K.; Shah, A. C.; J. Pharm. Biomed. Anal. 1994, 12,343 .

17. Logan, B. K.; Friel, N. P.; Peterson, K. L.; Predmore, B. B.; J. Anal. Toxicol. 1995, 19, 61.

18. Vatalev, A. A.; Kireeva, A. V.; Volchenko, S. V.; Kuklin, V. N.; Sud. Med. Ekspert 2011, 54, 41.

19. Franceschi, L.; Furlanut, M.; J. Bioanal. Biomed. Anal. 2010, 2, 121.

20. Qandil, A. M.; Tashtoush, B. M.; Taani, B. M.; Al-Nabulsi, S. M.; AlZogout, F.; Chromatographia 2008, 67, 287.

21. Wang, Z.; Dsida, R. M.; Avram, M. J.; J. Chromatogr., B: Anal. Technol. Biomed. Life Sci. 2001, 755, 383.

22. Squella, J. A.; Lemus, I.; Sturm, J. C.; Nunez-Vergara, L. J.; Anal. Lett. 1997, 30, 553.

23. Tsina, I.; Tam, Y. L.; Boyd, A.; Rocha, C.; Massey, I.; Tarnowski, T.; J. Pharm. Biomed. Anal. 1996, 15, 403.

24. Flores-Murrieta, F. J.; Granados-Soto, V.; Hong, E.; Boll. Chim. Farm. 1994, 133, 588.

25. Chaudhary, R. S.; Gangwal, S. S.; Jindal, K. C.; Khanna, S.; J. Chromatogr. 1993, 614, 180.

26. Wu, A. T.; Massey, I. J.; J. Chromatogr. 1990, 534, 241.

27. ICH (Q2B); Note for guidance on validation of analytical procedures: methodology, International conference on Harmonization, IFPMA: Geneva 1996. 